УДК 94(4):316

DOI: $10.24144 / 2218-5348.2019 .1-2(19-20) .48-58$

Бевзюк Свгеній, доктор історичних наук, професор

Табанюхова Олена, старший викладач ДВНЗ «Ужггородський наџіональний університет»

\title{
СТАНОВЛЕННЯ НАДНАЦІОНАЛЬНИХ ІДЕЙ У НАРОДІВ ЦЕНТРАЛЬНОЇ ЄВРОПИ
}

Майже у всіх етнічно споріднених народів, щчо входили до складу великих мовних і релігійних спільнот, на певному історичному етапі виникали неоднозначні за формою і змістом панідеологї - панславізм, пангерманізм, панамериканізм, панісламізм, і такі наднаціональні інтеграційні ідеї, як австрославізм, ілліризм. Їх мета полягала в обгрунтуванні не тільки цивілізачійної, етнокультурної, історичної спільності, але в тому числі $i$ політичної. 3 часом панідеї ставали не тільки джерелом для формування національної ідеології, але і слугували підставою для появи полінаціональних держав і забезпечували існування ідеології великодержавності.

Метою дослідження стала панідея, зокрема така ї̈ форма, як панславізм.

Ключові слова: начія, начіональна культура, ідеологія, імперія, пангерманізм, панамериканізм, панісламізм панславізм, ідея, демократія, свобода, національна ідеологія, регіон, етнос, Росія, Європа, слов'яни, зовнішня політика, геополітика.

National movement and further development of national benchmarks of the European peoples at the beginning of the revolution of 1848-1849 are one of the most socio-political contextualized pages in the past of the Slavik peoples in Europe. The research is considered to be topical since the process of formation of national ideology in the 19th century, that occured in the Slavs environment, took place in terms of distribution of the national principle and state formation in the majority of the European countries. The purpose of the research is to enlighten the course, laws and specifics of formation of the national paradigm at the beginning of the revolution of 1848-1849. The object of the study is the national movement of the Slavs, the subject of scientific analysis is the national ideology developing under the influence of both internal and external factors.

To achieve the main goal of the research the author has considered it to be necessary to solve a number of the following tasks: to scientifically, logically, 
argumentatively and coherently lay out specifics of the process of Slavic national ideology formation and reveal its main features. It should be emphasized that by the beginning of the revolution the national patriotic mood was not limited merely by the demand of the cultural reforms, it gradually transformed into the context of new political and socio-economic ideas. At the same time, in the meaning of national paradigm of the Slavic National Movement the idea of its moderation or passive opposition actualized drastically. In general national paradigm was a certain mixture of political ideas, in which political freedom - democracy, social and personal guarantees - took a somewhat secondary place, the struggle for the national justice with its moral and cultural principles, became dominant.

On the eve of the 1848 revolution western Slavs were involved in the process of modernizing their national ideology. Al though this process was an allEuropean phenomen on and large ethnic units were under going selfdetermination, the spiritual renaissance of the western Slavs had specific regional and ethnic characteristics, thus attracting the political attention of the governments of great empires - the Austrian and the Russian. For Russia, the biggest Slavonic country, the idea of the general Slavonic ethnic unity as well as the Pan-Slavistic ideology were not only of scientific character, but also served as a factor of geopolitical interest.

Keywords: nation, national culture, ideology, empire, Pan-Slavism, idea, democracy, freedom, national ideology, region, ethnos, Russia, Europe, Slavs, foreign policy, geopolitics.

Сам по собі панславізм, як його зміст, так i термінологічне наповнення, досі не отримав однозначної оцінки і тлумачення у вітчизняній i зарубіжній історіографії. Варто визнати, що в радянській історіографії існувала значна кількість досліджень, присвячених наднаціональним інтеграційним рухам. Відповідно в марксистській славістиці головна увага приділялася соціально-класовій традиції, а в історії розвитку ідеї слов'янської взаємності розглядалися ті концепції, які відповідали ідеології дослідження. Можна стверджувати, що русофільство чехів і словаків в умовах пролетарського інтернаціоналізму оцінювалося як один 3 витоків чехословацько - радянської дружби. В той самий час словацький сепаратизм, як і австрославізм, найчастіше піддавалися критиці. Тому заданий алгоритм ідеологізації при вивченні слов'янської історії привносив достатньо умовностей до термінологічного апарату досліджень.

Певним проривом у систематизації понятійного апарату стосовно проблеми слов'янської об'єднавчої ідеології та її ролі в національних рухах народів Габсбурзької монархії можна вважати кілька міжнародних конференцій, що мали місце в 60-х pp. XX ст. у Чехословаччині. Під час дискусії дослідники [4;13] дійшли висновку, що терміни «ідея слов'янської взаємності» $\mathrm{i}$ «панславізм», з огляду на набутий з часом високий змістовий 
рівень політизації, варто менше використовувати. В той самий час в марксистській історіографії було закономірним позитивно ставитися до ідеї слов'янської взаємності й підкреслювати реакційний характер панславізму. Така установка остаточно внесла термінологічну плутанину до змісту багатьох славістичних досліджень, а поняття i концепції слов'янської спільності й панславізму часто використовувалися на позначення одних і тих самих явищ. Зазначені обставини змусили нас уважніше розглянути зміст i значення ідеї панславізму для процесу становлення національної парадигми у західних слов'ян.

Метою нашого дослідження стала наднаціональна панідея, яка спирається на певні націоналістичні або релігійні ідеології, які декларують прагнення об’єднати представників близьких етнічних і мовник груп.

Варто погодитися з тим, що не в останню чергу зовнішньополітичні та воєнні успіхи Російської імперії стали причиною широкого теоретичного, а 3 часом й історико-політичного дискурсу навколо сутності i змісту наднаціональних інтеграційних всеслов'янських ідей, зокрема і панславізму конкретно. 3 огляду на заявлену вище проблему, розглянемо панславізм, враховуючи специфіку взаємовідносин у трикутнику інтересів - західні слов'яни, німецькі й угорські національні інтереси на тлі еволюціонування ідеї панславізму в контексті російсько-слов'янських стосунків й імперської зовнішньої політики.

Але перед тим, як визначати місце панславізму в змісті національних ідеологій західних слов'ян, цілком логічною буде наша спроба дослідити певну типологічність і закономірність появи панідей і панрухів як досить типових явищ у контексті становлення й розвитку національних ідеологій у Центральній і Центрально-Східній Європі першої половини XIX ст. Існують всі підстави стверджувати, що в історичному минулому можна знайти достатню кількість прикладів, які слугують ілюстрацією природності існування різного роду наднаціональних інтеграційних ідей. До того ж, варто вказати на притаманну розвитку великих i малих соціумів парадоксальну тенденцію. Її зміст лежить у діалектичній площині єдності і протилежності двох тенденцій - субрегіоналізації та регіоналізації. Майже у всіх етнічно споріднених народів, що входили до складу великих мовних спільнот, на певному історичному етапі виникають неоднозначні за формою і змістом панідеології - панславізм, пангерманізм, панамериканізм, панісламізм і такі наднаціональні інтеграційні ідеї, як австрославізм, ілліризм. Їх мета полягала в обгрунтуванні не тільки цивілізаційної, етнокультурної, історичної спільності, але в тому числі і політичної. 3 часом панідеї ставали не тільки джерелом для формування національної ідеології, але і слугували підставою для появи полінаціональних держав і забезпечували існування ідеології великодержавності. 
За допомоги порівняльного методу відзначимо характерні риси окремих згаданих вище панідей. Насамперед, своєю практикою інтродукції в геополітичний європейський простір відрізнявся пангерманізм. Він був зорієнтований на досягнення як політичної, так і культурної національної німецької єдності в рамках традиційного багатовікового політичного та історичного простору. Ідея панамериканізму, на відміну від пангерманізму, являє собою пантеорію, в основі якої ідея економічної єдності. Появу самої теорії варто вважати даниною географічній і геополітичній специфіці Американського континенту. 3 цього приводу Т.Джефферсон в одному із своїх виступів заявив: «Європейські нації утворюють окремий район земної кулі, відповідно їх місцезнаходження робить їх частиною іншої системи ... Америка має свою власну півкулю, а тому вона повинна мати свою окрему систему» [1, с.173]. Відповідно панісламізм, на відміну від згаданих вище панідей являє собою насамперед релігійно-політичну ідеологію, в основі якої - уявлення про релігійну єдність всіх мусульман. Звідси формується ідея необхідності консолідації мусульман у єдиній мусульманській державі.

Австрославізм, ілліризм також належать до числа наднаціональних інтеграційних ідей. Як відомо, перша являла собою програму перебудови Австрійської імперії у федеративну державу. Сама наднаціональна ідея австрославізму, вважає австрійський історик А. Морітч, конкретно передбачала перспективу реалізації проєкту надання чехам й іншим слов'янським народам автономії в рамках Австрійської імперії під скіпетром монархічної династії Габсбургів [12, s.11]. Процес появи наднаціонального австрославізму - це логічне продовження зростаючої політичної вагомості австрійського слов’янства в цілому. В ХІХ ст. Дунайська монархія стояла на порозі масштабної модернізації, однією 3 головних причин якої і була поліетнічність імперії. Країна, в якій фундаментальну політичну та економічну силу, вагомий людський потенціал являло слов'янство, не могла не враховувати цього у своїй внутрішній політиці. Достатньо сказати, що в австрійській армії, яка налічувала у мирний час 647 тис. чоловік, більше половини становило слов'янство, а частка чехів і словаків сягала лише 126700 чоловік (для порівняння: німців було 168800 чоловік, а угорців нараховувалося 42800 чоловік) [2, с.112-113].

Зауважимо, що ілліризм як інтеграційна ідея також припускав спочатку здійснення федералізації Габсбурзької імперії, а потім - утворення в iï межах Іллірійського королівства. Передбачалося до його складу приєднати території Хорватії, Славонії, Далмації. Сам ілліризм як наднаціональна ідея за своєю суттю був близьким до австрославізму. Головним теоретичним задумом ілліристів стала ідея побудови «Великої Іллірії», яка, на переконання хорватських національних діячів, мала би об'єднати всі південнослов'янські та деякі неслов'янські території. Підставою для існування цього наднаціонального інтеграційного проєкту 
було переконання еліти стосовно існування мовної та культурної близькості цих народів. У той самий час ідея ілліризму об'єктивно відповідала меті згуртування балканських слов'ян навколо імперії Габсбургів. Як бачимо, австрославізм, ілліризм також варто вважати наднаціональними інтеграційними формами, в основі яких - ідея федералізації Австрійської імперії за умови розвитку слов'янських націй.

Ідею наднаціональної слов'янської федерації підтримували також члени Кирило-Мефодіївського товариства. Ідеалом політико-державного устрою інтеграційного об'єднання слов'янських народів для членів товариства була демократична слов'янська федерація [9,c.150-152]. При цьому ідеологи товариства вбачали у створенні єдиного Слов'янського союзу можливий шлях здобуття Україною справжньої національної свободи, тому що обрання окремого шляху досягнення самостійного політичного існування для України вони вважали досить складним процесом. Члени КирилоМефодіївського товариства запропонували власний варіант панславізму. Програмні вимоги товариства передбачали створення панслов'янської федерації демократичних республік, які будуть мати демократичне правління за рівноправності всіх громадян. У той самий час, визнаючи право на широку автономію для кожного народу, що увійдуть до союзу націй, кириломефодіївці припускали, що основною дипломатичною мовою в союзі повинна стати російська $[8$, с.39]. Також передбачалося знищення у новому Слов'янському союзі кріпацтва i станових привілеїв. Отже, кириломефодіївський варіант також являв собою демократичну, але в той же час наднаціональну інтеграційну ідею.

У зв'язку із викладеним вище вважаємо, що варто визначити специфічні риси панславізму. Особливістю становлення i розвитку панславізму як одного з видів інтеграційних наднаціональних ідей стало його походження з ідеї етнічної, мовної, культурної і конфесійної спорідненості слов'янських народів. На нашу думку, ідею конфесійної близькості не варто розглядати як один із атрибутів, що супроводжував еволюцію національної ідеології західного слов'янства. 3 приводу існування та взаємодії двох великих християнських напрямів (православ'я та католицизму) на етнічній ниві західного слов'янства необхідно зазначити, що у переважній більшості західнослов'янські інтелектуали не ототожнювали духовність й історію свого народу із духовно-релігійним алгоритмом православ'я. Хоча на цю тему слов'янськими національними теоретиками інколи і здійснювалися певні концептуальні інтерпретації. Їх поява, на нашу думку, була обумовлена не стільки специфікою часу і місця, скільки світоглядною і релігійною позицією ïx інтерпретаторів. Для прикладу, російський славіст XIX ст. П.Кулаковський пропонував своє прочитання творів слов'янських національних будителів. Він стверджував, що будителі ідеал слов'янської єдності розглядали не просто як літературну єдність, а, скоріше, як процес духовно-релігійної 
інтеграції, коли фактичне зближення слов'ян приведе народи «до повного, a, відповідно, і до релігійного їх об'єднання». При цьому П. Кулаковський, спираючись на ідеї словака Л.Штура, намагається дати таку інтерпретацію спадщини словацького будителя: «Штур як ... щирий, глибокий слов'янський діяч ... прямо визнавав лише один правильний вихід із слов'янської розрізненності - єднання усіх у релігійному відношенні і повернення до православ'я із всіма наслідками, що випливали б з цього» $[6$, с. 232]. Зрозуміло, що така інтерпретація ідей Л. Штура мала право на своє існування. Але, на нашу думку, конфесійний фактор, без сумніву, здійснив значний вплив на появу панславістичних ідей у середовищі південних слов'ян - сербів, чорногорців, болгар, македонців i, безумовно, тієї частини українців Галичини, які сповідували православ'я. До речі, з приводу останніх наявний архівний матеріал дозволяє стверджувати, що царський уряд намагався надавати духовну підтримку православним слов'янам. Відома доповідна записка генерал-майора Муравйова. Він спрямував до Святійшого синоду записку, в якій не тільки описав становище православних слов'ян Австрійської імперії, але й виклав свої пропозиції з приводу можливих форм і обсягів допомоги. Записка потрапила до імператора Миколи I. Про цей факт ми можемо дізнатися із примітки, що зробив своєю рукою на записці оберпрокурор синоду Н. Протасов. Він написав: «Повідомлено його імператорській величності в Царському Селі 1 листопада 1838 року. Государ імператор височайше схильний затвердити заходи, які були запропоновані, та наказав обговорити із графом Нессельроде можливість надіслати православним Австрії через посольство духовні книги»[7]. Як бачимо, російський уряд підтримував православ'я.

У той же час було б занадто категорично й упереджено стверджувати, що католицизм, а тим більше протестантизм, у середовищі західного слов'янства знаходилися в стані тяжкої кризи, а це, в свою чергу, було однією 3 причин їх критики західними слов'янськими національними ідеологами на користь православ'я. Як нами вже відзначалося, ідеологи будителі в процесі побудови національного контенту мовної емансипації спиралися як на національно-патріотичну ідеологію, так і на технологію антагонізму. До речі, технологія антагонізму була не менш зручним засобом для політизації проблеми співіснування слов'янської й німецької культур, католицизму із православ'ям. Цю тему в тій чи інший мірі зачіпали, досліджували, а інколи і розкручували «маховик взаємного протистояння» в XIX ст. - В.Ф.Тімковський, М.П.Погодін, Я.Коллар, В.Ганка, О.Ф.Гільфердінг, М.І.Костомаров, В.Богуславський, Ф.Енгельс, Л.Штур. Для обгрунтування свого бачення змісту процесу відродження окремими теоретиками обиралися такі факти з історії і релігії, які могли б підкреслити негативні наслідки окатоличування західного слов'янства. При цьому подібний ідеологічний прийом у національій боротьбі варто вважати 
нетиповим для будителів - вихідців із слов'янського середовища. Швидше за все антагонізм стосовно протиріч між католицизмом і православ'ям у якості аргументу в змісті інтеграційної наднаціональної ідеї обирали теоретики слов'янофільського або російського панславізму, а не західні слов'янські будителі.

Розглядаючи процес становлення національної парадигми у західних слов'ян у контексті панславістичної ідеї, зазначимо, що саме «тяжіння до спільності» на тлі етнічного минулого, а останне і становить, власне, суть ідеї, було природним духовним явищем, тому розвиток чеської, словацької, лужицької літературних мов протягом XIX ст. іманентно супроводжувався філософією спільності, яка в часи становлення націй оволоділа думками багатьох творчих особистостей на теренах германо-слов'янського простору. У той же час, на думку сучасної славістики, твердження про масштабність інтродукції західного слов'янського соціуму до змісту ідеології панславізму є певним перебільшенням. Однозначно можна говорити, що в середовищі західних слов'янських національних ідеологів спостерігалося прагнення до розмежування панславізма та русофільства.

Безпосередню оцінку національних концепцій західних словянських інтелектуалів необхідно надавати із врахуванням ідеології, міжнародної i політичної ситуацій, в яких відбувалася інтерпретація наявних фактів. Відомо, що лідери західного національного руху періоду становлення громадянського суспільства, і навіть словак Л.Штур, не раз публічно дистанціювалися від царофільського панславізму. В той самий час культурний панславізм досить часто ставав для них опорним точковим поняттям ву процесі власної ідентифікації та на шляху побудови національної ідеологеми [3, с.122].

У розрізі нашого дослідження для нас особливо цікавим буде такий тип політичного панславізму, як слов'янофільський, або російський панславізм. Його прихильники припускали думку про можливість об'єднання слов'янських народів навколо Росії. Як відомо, подібний варіант інтерпретації панславізму в тій або іншій мірі розглядався і Л.Штуром. Варто прокоментувати позицію словацького будителя рядками 3 його листа до невстановленої особи. В листі Л.Штур, незважаючи на імідж національного слов'янського патріота, критично висловлювався на адресу польських політиків, які втілювали в практику своєї національної програми ідею протистояння російській імперській експансії. «Ваш шлях, - писав словацький національний ідеолог, - не запозичений зі слов'янської ідеї, тому що ви з ким завгодно об'єднуєтеся, ... але об'єднуєтеся і в тому числі із нашими ворогами проти своїх братів» [11, s.195].

Кінцеве оформлення штурівський панславізм отримав у трактаті «Слов'янство і світ майбутнього. Послання слов'янам з берегів Дуна». 3 огляду на те, що хронологічно трактат з'явився в 1851 р., одразу ж після 
завершення революції 1848-1849 рр., ми вважаємо за доцільне включити штурівську працю у наше дослідження. Додамо, що до кінця залишаються незрозумілими причини, які спонукали Л.Штура до написання трактату. В той самий час варто нагадати, що за неповні три троки до появи праці «Слов'янство і світ майбутнього» словацький будитель, будучи делегатом Празького конгресу, не висловлював русофільських думок та не проголошував гасел про необхідність об'єднання всіх слов’янських народів під скіпетром Російської імперії.

Загальні риси наднаціональної концепції словацького будителя зводилися до думки про існування тенденції, за якою статус Росії як найбільшої слов'янської держави дозволяє припустити можливість побудувати на федеративних засадах оновлену загальнослов'янську монархію. У своєму трактаті Л.Штур виклав поетапну програму досягнення наднаціональної слов'янської інтеграції. Спочатку передбачалося утворення федерації слов'янських держав. У той же час у межах Австрійської імперії західне і південне слов'янство мало би поступово перетворитися на рушійну силу якісних національних змін у самій імперії. Завершальною стадією масштабного наднаціонального інтеграційного процесу мало би стати приєднання слов’янства до Росії [10, с.133].

Зазначимо однак, що проєкт утворення слов'янської федеративної i республіканської держави сам Л.Штур вважав нереальною мрією, тому що практичний бік проєкту «з самого його початку, - писав словацький національний ідеолог, - вимагав викреслити царську Росію і ті племена, які або вже увійшли до іiі складу, або визнали за міжнародним правом факт іiі заступництва» $[10$, с.119]. За таким сценарієм на практиці до складу нової слов'янської федерації могли би увійти лише слов'янські піддані Габсбурзької корони, що в кінцевому підсумку «вихолощувало» саму штурівську ідею наднаціональної всеслов'янської інтеграції. Відповідно, розвиває далі свою думку Л.Штур, перед Росією на шляху досягнення нею статусу лідера слов'янського світу стоїть завдання здійснити зовнішньополітичні і внутрішньополітичні трансформації. Насамперед Східна імперія, розвиває свою думку Л.Штур, має знищити кріпосне право, «зловісну таємну поліцію» i назавжди відмовитися від таких зовнішньополітичних союзів, які «лише підгодовуються заради збереження вже падаючих, а також безпорадних династій і престолів» [10, с.163-164]. Такі радикальні суспільно-політичні реформи, на думку словацького будителя, дозволили б не тільки підтримати етнонаціональну ідентичність кожного слов'янського племені, але водночас були б умовою для розширення міжслов'янської інтеграції.

Проросійський панславізм як ідеологія в подальшому отримав свій концептуальний розвиток у рамках слов'янофільства, що, безумовно, було підставою для його багатолітньої критики 3 боку наступного покоління 
політиків, публіцистів і науковців. Наприклад, відомий американський дослідник націоналізму Ганс Кон дійшов висновку, за яким «панславізм ... був рухом за поширення влади Росії за допомогою включення інших слов'яномовних народів, навіть проти їх волі, у «Велику Росію», населення і економічні ресурси якої створили б достатню базу для світового панування Росії» [5, с.89-91]. Поступово в історичній практиці сама ідея панславізму за своїм змістовим наповненням ставала дедалі більш неоднорідною, а термін «панславізм» все більш розпливчастим і неоднозначним. Відповідно, незважаючи на генезис панславізму як наднаціональної ідеї, він так і не набув значення загальнослов'янської інтеграційної ідеології, не надбав форми загальнослов'янської свідомості, а являв собою лише набір різноманітних панславістських теорій і поглядів його прихильників.

Підсумовуючи, зазначимо, що панславізм та спроба репродукувати на його тлі ідею загальнослов'янської свідомості ніколи не були винятково прогресивними факторами. Проти волі його фундаторів він все ж був приречений входити в суперечність 3 етнічною самосвідомістю, з інтересами кожного окремо взятого слов'янського народу i процесом його самовизначення. Отже, на певних етапах розвитку західних слов'янських народів загальнослов'янська свідомість не тільки не сприяла розвитку національної свідомості, але і перешкоджала закріпленню національного принципу, будучи більш архаїчною, міфологізованою та заснованою на етнічних стереотипах, які $є$ консервативними за своєю суттю.

В процесі слов'янського націотворення виділилося і сформувалося нове інтелектуальне ядро, яке в умовах тиску з боку активних німецьких $\mathrm{i}$ угорських національних прагнень розпочало творення власної еволюційної політичної програми. В той же час варто визнати, що слов'яни Центральної Європи в XIX ст. визначили досить скромну мету свого руху - визнання їхньої мови, історії і національної своєрідності. Можна стверджувати, що перелічені складові стимулювали у певної частини суспільства появу національної ідеології, а в подальшому і її пропаганду. При цьому, як ми вже відзначали вище, певним ідеологічним атрибутом на шляху еволюції слов'янських народів до зрілої нації була панідея, одним із символів якої виступила слов'янська Росія. Водночас специфікою російського панславізму стало те, що він розвивався в Східній імперії в руслі формування російської національної ідеї. Відповідно Росія на європейському геополітичному полі намагалася підтримувати свій всеслов'янський статус, що, безперечно, ставало дискусійним матеріалом не тільки для пангерманістів, австрофілів, але й для ліберальних та консервативних ідеологів наднаціонального австрославізму.

Щодо присутності ідеї русофільства i царофільства у змісті національних ідеологій західних слов'ян і їх критики варто зазначити таке: актуалізація самих ідей у першій половині XIX ст., подальша їх політична 
інтерпретація досить часто ставали наслідком надуманих та привнесених теоретико-ідеологічних проєктів. Їх варто вважати як іманентною частиною у змісті ідеології національних слов'янських рухів, так й ідеями, що привносилися до слов'янських народів і стимулювалися ззовні.

3 огляду на сказане, цілком логічно припустити, що західнослов'янські інтелектуали, вочевидь, все ж усвідомлювали суперечливість, вагомість і місце слов'яно-російського компонента у змісті проєкту своїх національно-культурних прагнень. Хоча в той же час вони не заперечували «посередницьких» послуг російського «образу» i наднаціональної панславістичної ідеї, що їх вони інколи опосередковано все ж використовували у якості «важеля тиску» на свій уряд. Такі дії, прояви взаємозв'язку зазвичай супроводжувалися досить емоційним фоном і часто призводили до появи суб'єктивних та упереджених суджень. Зазначимо однак, що політичну позицію, в якій була відсутня об'єктивність в оцінці панславізму, на нашу думку, можна також зрозуміти. На етапі націотворення та в період високої міжнаціональної конкуренції благородна мета захисту власної етнічності, збереження i розвитку своєї культури i мови виправдовувала пропагандистські засоби їх досягнення.

\section{Список використаних джерел}

1. Антясов М.В. Панамериканизм: идеология и политика. М., 1981. 293 c.

2. Гильфердинг А.Ф. Славянские народы в Австрии и Турции / Статьи по современным вопросам славянским. СПб., 1868. Т. 2. С. 12-113.

3. Загора Роман. Идеолог словацкого национального возрождения Людовит Штур и представители российских общественных и научных кругов в 1830-х первой половине 1850-х гг. Санкт-Петербург, 2011. 162 с.

4. Колейка Й. Славянские программы и идея славянской солидарности в XIX и XX веках. Praha: Statni ped. Nakl-vi, 1964. 264 с.

5. Кон Ганс. Национализм: его смысл и история // Проблемы Восточной Европы. Вашингтон. 1994. № 41-42. С. 88-169. URL: http://www.traditio.ru.htm.

6. Кулаковский П.А. Иллиризм: Исследования по истории хорватской литературы периода Возрождения. Варшава1894. 411 с.

7. О положении православия и унии в австрийских владениях. Секретно // РГИА СПб. Ф. 797. ОП. 8. Ед.хр. 24170.

8. Семевский В.И. Н.И.Гулак // Галерея шлиссельбургских узников. СПб., 1907. Ч.І. 298 с.

9. Статут Кирило-Мефодіївського товариства 1845 - кінець 1846 р. // Кирило-Мефодіївське товариство: У 3-х Т. К.: Наук. думка, 1990. Т. І. $544 \mathrm{c}$. 
10. Штур Л. Славянство и мир будущего. Послание славянам с берегов Дуная. М.: В унив. тип. (Катков и Ко), 1867. 199 с.

11. Listy L'udovíta Ńtúra / Vyd. J. Ambrus. II. S. 19 -196; 456-459.

12. Moritsch A. Der Austroslavismus - ein verfrühtes Konzept zur politischen Neugestaltung Mitteleuropas / Der Austroslavismus: ein verfrühtes Konzept zur politischen Neugestaltung Mitteleuropas. Wien: Böhlau Verlag, 1996. S. 11-23.

13. Ńt’astný Vladislav. Slovanství v národním n̦ivotě Ĉechů a Slováků. V Praze: Pro Ústav dějin evropských socialistických zemí ĈSAV vydalo nakl. Melantrich, 1968. $500 \mathrm{~s}$.

\section{REFERENCES} $293 \mathrm{~s}$.

1. Antyasov M.V. (1981). Panamerikanizm: ideologiya i politika. M.

2. Gilferding A.F. Slavyanskie narodyi v Avstrii i Turtsii / Stati po sovremennyim voprosam slavyanskim, t. 2, pp. 12-113.

3. Zagora Roman. (2011). Ideolog slovatskogo natsionalnogo vozrozhdeniya Lyudovit Shtur i predstaviteli rossiyskih obschestvennyih i nauchnyih krugov v 1830-h pervoy polovine 1850-h gg., $162 \mathrm{p}$.

4. Koleyka Y. (1964). Slavyanskie programmyi i ideya slavyanskoy solidarnosti v XIX i XX vekah. Praha: Statni ped. Nakl-vi,-264 s.

5. Kon Gans. Natsionalizm: ego smyisl i istoriya // Problemyi Vostochnoy Evropyi. Vashington. 1994. № 41-42. C. 88-169. http://www.traditio.ru.htm.

6. Kulakovskiy P.A. (1894). Illirizm: Issledovaniya po istorii horvatskoy literaturyi perioda Vozrozhdeniya. Varshava1894. $411 \mathrm{~s}$.

7. O polozhenii pravoslaviya i unii v avstriyskih vladeniyah. Sekretno // RGIA SPb. F. 797. Op. 8. Ed.hr. 24170.

8. Semevskiy V.I. (1907). N.I.Gulak // Galereya shlisselburgskih uznikov. SPb., 1907. Ch.I. 298 s.

9. Statut Kirilo-MefodIYivskogo tovaristva 1845 - kInets 1846 r. // Kirilo-MefodIYivske tovaristvo: U 3-h T. K.: Nauk. dumka, 1990. T. I. 544 s.

10. Shtur L. (1867). Slavyanstvo i mir buduschego. Poslanie slavyanam s beregov Dunaya. M.: V univ. tip. (Katkov i Ko), 1867. 199 s. 